\title{
REGIONALIZATION OF SERBIA AS AN INSTRUMENT OF BALANCED REGIONAL DEVELOPMENT AND REDUCTION OF REGIONAL INEQUALITIES
}

\author{
Rajko Golić ${ }^{*}$, Marko Joksimović ${ }^{*}$ \\ "University of Belgrade - Faculty of Geography, Belgrade
}

\begin{abstract}
Regionalization of Serbia in the second half of the 20th century was characterized by the dominance of the traditional approach, based on classical understanding of region as a static physiognomic spatial unit, with some attempts at economic regionalization. Such regionalizations were largely inapplicable in practice, so that they did not become part of legislative related to the planning of a balanced development of the territory of Serbia. Decentralization in socialism did not yield expected results, and after political changes in the late 20th century, Serbia became a highly centralized state. The modern concept of regionalization is relatively new in Serbia. Regional dimension of development has become the subject of scientific research in the last few decades, which is conditioned by the growing economic and demographic disparities between different parts of the state. Creating a NUTS regions in Serbia in 2009 was the first step towards modern regionalization. However, NUTS regions in Serbia do not have autonomy in regional governance and can not be able to decrease developmental disparities and support long-term economic and social development. It is therefore necessary that these territorial units get appropriate competencies in governance and decision-making, which would ensure de facto decentralization of the state and give a clear sense to the newly formed regions.
\end{abstract}

Key words: Serbia, regionalization, regional development, regional inequality, NUTS regions.

${ }^{1}$ Corresponding author: R. Golić, University of Belgrade - Faculty of Geography, Studentski trg 3/III, 11,000 Belgrade, Serbia; e-mail: rgolic@gef.bg.ac.rs 


\section{Introduction}

During the 20th century, the work on regionalization of the geographical area of Serbia was not developed in accordance with the needs of the society. Regionalization was not given enough attention in spite of rich scientific geographical heritage. Initiation of regional concept into Serbian and $\mathrm{Yu}-$ goslav geography begins in the decades after the Second World War, when Serbian geographers began to pay more attention to the problem of regionalization of Serbia. Some of these attempts of regional division only related to the territory of Serbia (Đurić, 1959; Milojević, 1955; Vasović, 1965, etc.), while others treated territory of Serbia within Yugoslavia, in scientific works (Ilešič, 1961; Kubović, 1961; Malovrh, 1959; Obradović, 1955; Petrović, 1957; Rogić, 1973; Roglić, 1955, etc.) and in university textbooks (Marković, 1967; Melik, 1949). However, these regionalization attempts were characterized by the dominance of the traditional approach, based on the classical understanding of the region as a static natural or physiognomic spatial unit, along with some attempts at economic regionalization based on economic and functional regions. For example, Vasović's regionalization of Serbia (1965) is based on the physiognomy of geographical landscape; Đurić (1959) starts from the assumption about the functional connection of heterogeneous spatial units; Melik (1949) and Marković (1967) divide the territory of Yugoslavia and Serbia into the largest natural-geographical areas; while Ilešič (1961) elaborated a dual (physiognomic and economic-functional) regionalization. Despite certain attempts, such regionalizations were almost exclusively academic, largely inapplicable in practice, so that they did not become part of official strategic documents or legislative regulations related to the planning of a balanced development of the territory of Serbia. According to Adžić (2015), Serbia did not succeed to define good regional policy in that period.

The modern concept of regionalization, by which region is perceived as a means and instrument for more balanced economic, social and environmental development and more rational use of natural and demographic resources, is relatively new in Serbia. Regional dimension of development has become the subject of scientific research in the last few decades, which is conditioned by growing economic and demographic disparities between different parts of the state. Although the functional approach in Serbian regional geography has been present since the 1970s (Тошић, 2012), the problem of planned regionalization of territory of Serbia, with the aim of creating an optimal spatial structure that will alleviate regional disparities, is still being given relatively little attention. 
In contemporary concepts of spatial development, regional policy and "new regionalism", regionalization is primarily seen as a form of decentralization of power and decision-making, the essence of which is the transfer of competencies from the central (state) level to the lower regional levels (regional self-government) with the aim of enable a more balanced development of all parts of the territory (Ilić, 2015; Lončar, 2009; Olfert, 2016), but also better exploit the possibilities of integration and connectivity with the regions of other states (cross-border cooperation, euroregions, etc.). In this regard, the region is viewed as a dynamic category, defined not only on the basis of the nature and physiognomy of space, but above all on the basis of statistical indicators and indicators of economic and demographic development. Regions are no longer abstract and academic creations, but real territorial entities with clear responsibilities, which are formalized through the constitution, laws and other legal acts. Such institutional regionalization and creation of regions as political or administrative units with a certain degree of autonomous decision-making in Serbia is still at the beginning. The scientific circles in Serbia are increasingly accepting opinion that functional regionalization is imperative in creating a model of sustainable spatial development of Serbia (Тошић, 2012). Therefore, regional policy, regionalization and decentralization in the current process of harmonization of legislation with the legislation of the European Union imposes itself as one of the imperatives of the future development of Serbia.

\section{Administrative regionalization of Serbia in the past}

In the past two centuries, territory of Serbia has undergone frequent and different administrative-territorial changes. Since gaining autonomy in the Ottoman Empire until the Second World War, regional division of the state has been changed several times, starting from the nahiye (Serbian: nahije), knežinas (knežine), captaincies (kapetanije), oblasts (oblasti), commands (serdarstva), okružjas (okružja) and districts (okruzi) in Principality of Serbia, districts in Kingdom of Serbia, oblasts in Kingdom of Serbs, Croats and Slovenes, to the banovinas (banovine) in Kingdom of Yugoslavia. Changes in the territorial organization of the state in this period were very common at all levels, and the transfer of some settlements and municipalities from one county (Serbian: srez) to another was a common occurrence (ZSNRS, 1955). All the official regional divisions of Serbia before the Second World War were based on the tradition of the former historical and geographical units and had only administrative and administrative function. At 
that time, the concepts of "regional development" and „regional inequalities" were unknown, so that the separated territorial units did not have almost any development function at the regional and local level.

After the end of the Second World War, in 1945, two areas with a special status were separated in Serbia - Autonomous Province of Vojvodina and the Autonomous Kosovo-Metohija region (Vacić, Mijatović, Simić \& Radović, 2003). Pre-war banovinas were abolished, and in the first years after the war, Serbia was divided into districts (Serbian: okruzi), which had its counties (Serbian: srezovi) composed of several local people's committees (Serbian: mesni narodni odbori). Districts were abolished in 1947. In 1949, the territory of Serbia without today's autonomous provinces (so-called Central Serbia) was divided into five oblasts: Belgrade, Kragujevac, Niš, Timok and Užice. The oblasts consisted of counties, but were abolished in 1951 (Milosavljević, 2015).

After the abolition of local people's committees (1952), municipalities were formed and two-level administrative division was established (counties and municipalities) (Đurđev, 2007). The adoption of the "General Law on the areas of the counties and municipalities" (Official Gazette of Yugoslavia, 26/1955) marks the beginning of the development of the so-called "communal system" and affirmation of municipalities as basic and most important units of territorial division. Municipalities have become the main political and territorial organizations of self-management and the basic socio-economic community of inhabitants in their areas. They take up a major part in carrying out entrusted state affairs. On the other hand, the counties appear as derived units of regional importance, which perform tasks of common interest for municipalities, but they have more limited competencies in relation to the previous period (Milosavljević, 2015).

After the establishment of the communal system, the consolidation of municipalities was carried out and their number was reduced by bringing together smaller ones into one larger. The reduced competencies of the counties have raised the question of their existence. The counties were abolished in Kosovo and Metohija in 1959, in Vojvodina in 1965, and in Central Serbia in 1967 (Milosavljević, 2015). With the annulment of counties, territorial division of Serbia became one-levels; there were no territorial units (regions) of medium size that would play the role of intermediaries between republican authorities and local self-governments (municipalities). In this way, the tradition of administrative division into middle-sized regions (nahiye, districts, banovinas, counties, etc.), established in the first half of the 19th century, was abolished, and Serbia became extremely centralized. 
After abolishing of counties, resulting centralized system soon showed its shortcomings. The absence of a medium-sized region has led to the coordination and cooperation of neighboring municipalities in affairs of common interest almost interrupted. The realization of joint projects and plans for the development of economy and infrastructure between municipalities was at a very low level (Milosavljević, 2015).

The expressed need for a greater degree of decentralization and the creation of a regions that would replace the former counties led to the formation of inter-municipal regional communities (IMRC), after the adoption of the new Constitution of the SFR Yugoslavia and the Constitution of the Socialist Republic of Serbia in 1974. At the territory of Central Serbia, 15 IMRCs were formed at that time, the borders of which mostly coincided with the areas of the former counties. In 1975, their number was reduced to eight: Podrinje-Kolubara, Titovo Užice, Kraljevo, Šumadija and Pomoravlje, Podunavlje, Zaječar, Niš, and South Pomoravlje (Map 1). These regional units are not created on the territory of atonomous povinces (Vojvodina and Kosovo and Metohija); the city of Belgrade was also not part of the IMRC (Đurđev, 2007; Milosavljević, 2015). IMRCs are the only attempt to divide Serbian territory into macro-regions under socialism (Tošić \& Maksin-Mićić, 2007).

IMRCs represented a form of regionalization in which municipalities freely associate in order to achieve permanent cooperation, planning, harmonization and adoption of joint development plans and programs, realization of joint development projects in the territory of two or more municipalities, as well as for the realization of other common interests (Đurđev, 2007). IMRCs received certain competencies that had been exercised by the republic authorities (top-down decentralization), but also municipal authorities (bottom-up decentralization). The main role of these communities was to coordinate the development and other interests of the associated municipalities, but also to carry out a large number of entrusted tasks within the competence of the Republic. Each IMRC had an assembly (delegated representatives of municipalities), executive and administrative authority, services with different competencies, revenues and finances, as well as a certain independence in the adoption and implementation of development plans and programs, personnel policy, etc. Regional branches of socio-political organizations, regional self-governing interest communities, chambers, cooperative associations and other organizations have been formed in the territory of each IMRC (Milosavljević, 2015). However, these macro regions never had all necessary administrative and control functions and did not enjoy the desired degree of autonomy. Although they disposed of specified 
investment funds and had the authority to direct regional development, they never took root completely and did not persist (Tošić \& Maksin-Mićić, 2007). Nevertheless, IMRCs represented constituencies for republican and federal assemblies, which gave Serbia the character of a regional decentralized state.

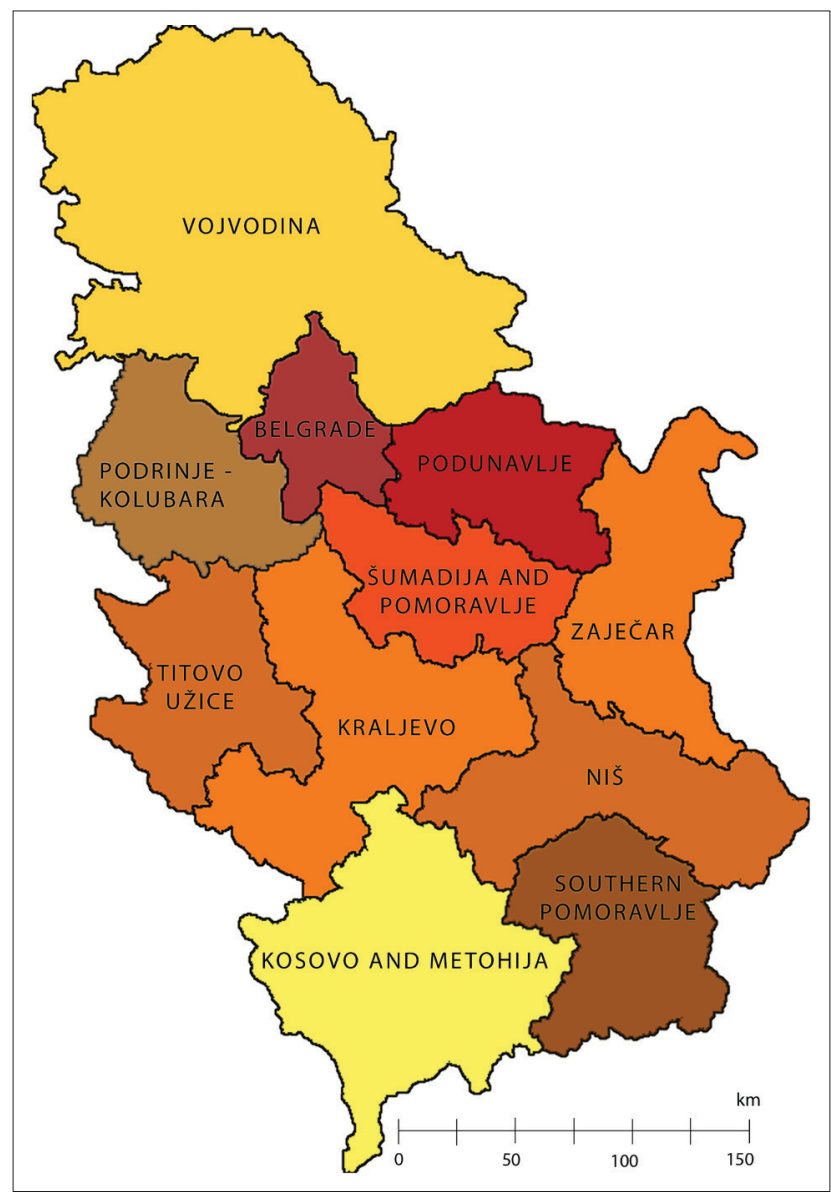

Map 1 - Inter-municipal regional communities in the Central Serbia (1975-1990)

Source: Map processed by authors based on RZS, 1986.

This regional and decentralized organization of the state continue until 1990, when new Constitution of Serbia began a period of re-centralization. In this Constitution (Official Gazette of the RS, 1/1990), not only about 
regionalization and decentralization was not mentioned, but only right to regional organization was suspended. Authorities have striven to govern according to so-called „electoral authoritarianism”, which was more suited to the centralized structure of the state (Milosavljević, 2015). As a form of regionalization and decentralization, IMRCs were omitted from the Constitution and abolished by the adoption of the "Law on territorial organization of the Republic of Serbia and local self-government" in 1991 (Official Gazette of the RS, 47/1991). The rights and obligations of the IMRCs have been taken over by the Republic, which has also centralized large number of competencies that municipalities had previously performed, which greatly prevented or made it difficult to achieve development goals at the local and regional level. Thus, municipalities lost their function and were brought into a financial and any other dependence on the will of the state authorities. In this way, process of regionalization and decentralization, initiated by the establishment of the IMRCs in 1974, was abruptly discontinued. Centralization of decision-making has minimized the possibility for local governments to manage the development of their communities.

Centralization was confirmed in 1992, when new state - Federal Republic of Yugoslavia (FRY) with the member states of Serbia and Montenegro was formed by passing the Constitution. During this period of central government, there was no possibility to start any form of regionalization of Serbia in order to achieve territorially more balanced development, because for that there was no constitutional or legal basis, and development of the state took place in extremely complex and difficult socio-political circumstances (wars, social and economic crisis, political conflicts with the international community, economic isolation, etc.). This period created a poor country with great regional imbalances and consequences that a large number of citizens still feel.

In 1992, Serbia was divided into 29 districts (seven in Vojvodina, five in Kosovo and Metohija and 17 in Central Serbia), with the city of Belgrade as a separate administrative area. At first glance, districts are a form of regionalization and decentralization of the state territory, since they consist of municipalities and cities, have a territorial framework and boundaries within which the powers of the district authorities extend. However, in reality, the districts are not units of regional or local self-government, nor territorial units, but have been formed for the purpose of performing state administration activities outside the headquarters of the authorities in Belgrade. In other words, they can be defined as a form of spatial deconcentration of centralized state administration (Milosavljević, 2015; Vacić et al., 2003), and not as territorial decentralization with goal of easier solving development prob- 
lems. Therefore, the districts can't be seen as a new model of regionalization aimed at creating conditions for a more balanced regional development and alleviation of regional inequalities.

\section{Modern approach to regionalization of Serbia}

Observing the changes in its territorial organization in the 19th and 20th centuries, it is noted that Serbia has been transformed from an extremely decentralized regional state (at the end of the 19th century) into an extremely centralized state with a strong central government and its "extended arm" (districts), and without a middle level of regional administration, excluding Vojvodina and Kosovo and Metohija with a very limited autonomy (end of 20th century) (Stojkov, 2007).

The idea of regionalization of Serbia on modern principles, as one of the possible solutions of its territorial organization, appeared in the mid-1990s (Lončar, 2009), although in conditions of the centralist system and authoritarian authorities it did not have the possibility for practical application. Nevertheless, need to reduce regional inequalities through more balanced regional development has been increasingly present in society. One of the first initiatives for changing the centralist model was initiated by the "Spatial plan of the Republic of Serbia" (1996), when a system of functional nodal centers of different hierarchical levels was established, from macroregional (Belgrade, Novi Sad, Priština, Niš, Kragujevac and Užice), through regional to subregional. However, the boundaries of the gravitational zones of the proposed nodal centers have not been clearly established, so that in spatial sense they have not been defined in the corresponding regions (Prostorni plan Srbije, 1996). It can be noted that all attempts to regionalize Serbia in the 20th century have not produced any significant effect on the integration and balanced development of its territory, so they are unable to provide a basis for Serbia's future regionalisation in accordance with EU principles and policies (Tošić \& Maksin-Mićić, 2007).

Although the question of regionalization of Serbia is more or less the current topic for the past 20 years, there are still opposing views on the issue in public. Public opinion in Serbia refers to regionalization with great distrust and resistance, or with too much and unrealistic expectations. Thus, for example, at the end of the 20th century, central government has often experienced regionalization as an attack on state sovereignty, and representatives of local government as a potential competitor (Lončar, 2009). Many citizens of Serbia continue to believe that regions, as a decision-making decentraliza- 
tion model, represent a timed bomb in the heart of the state, in terms of strengthening separatist tendencies, political autonomy and nationalist aspirations of minorities, which ultimately can lead to the continuation of the disintegration of state territory, started in the last decade 20 century.

The dynamics of interest about regionalization in contemporary Serbia was conditioned by political changes. Until the end of the 20th century, the idea of regionalization was mainly promoted by the non-governmental sector. After the democratization of society in 2000, representatives of official state bodies began to deal with this issue, which made regionalization part of Serbia's political life (Lončar, 2009). However, under the term regionalization, representatives of state authorities often assumed different concepts - from territorial autonomy in a unitary state, through a regional state to a federalization.

Despite the growing number of regionalization supporters, in the Constitution of Serbia (Official Gazette of the RS, 98/2006), regionalization was not legalized as a new model of territorial organization, and Serbia is defined as a unitary state with two autonomous provinces. Instead of regionalization, in order to overcome the growing problem of developmental inequalities, the Constitution envisages the obligation of the state to ensure balanced and sustainable regional development. However, very little has been achieved in the implementation of this constitutional obligation; the economic development of municipalities and cities in Serbia still fully depended on the central government.

It is indisputable that today Serbia needs a very active policy of balanced regional development. The decades-long neglect of the development of many rural and peripheral parts of the state makes regional differences continually deepening, so today Serbia is among the states with the highest developmental disparities in Europe. In Serbia, regional disparities are enormous in comparison with European standards; the in gross domestic product (GDP) range from 1:7 (districts) to 1:15 (municipalities). Public and academic elite are fully aware of the link between economic development and regional self-government, the huge regional disparities and the probable and already present consequences of centralization and „belgradization” of the state (Takács \& Nagy, 2013).

The expansion of the idea of regionalization of Serbia was undoubtedly contributed by the official policy of the European Union about the need for decentralization of decision-making from the national to the regional level, as well as the understanding that the regions are the main subjects of the development processes. After 2000, a numerous scientific papers and projects about European regional initiatives and models of regionalization was appeared, adapted to the specifics of the geospatial system of Serbia (Тошић, 2012). Not 
only did the European Union adapt its internal organization to the conduct of such a policy, but also through a numerous important documents about regional, rural and sustainable development gave a strong impulse to the process of regionalization in member states and candidate states, including Serbia.

Regional policy and the so-called „new regionalism”, which involves the creation of multilevel public management systems, are relatively new and very significant tendencies across Europe. Decentralization as a bottom-up development model, according to the experience of EU states, presupposes the association of local communities (municipalities, settlements) into territorial units (groups of municipalities) that can provide a certain level, quality and sustainability of management. The process of association of local self-governments leads to regionalization, that is, towards the formation of a middle level of governance that is capable of dealing with problems of economic and social development and reducing of regional inequalities. This model implies a decision-making process on lower-level from the state, and polycentrism as a policy that supports the development of a larger number of regional centers (Stojkov, 2007). In this way, the regions increasingly cease to be passive objects of national policies, and acquire the characteristics of open and dynamic development entities (Милетић, Тодоровић \& Миљановић, 2009). As a candidate for EU membership, Serbia began the process of adapting its legislation to this model.

Institutionalization of regional policy of Serbia began in 2007, when the „Regional development strategy of Republic of Serbia 2007-2012" was adopted, as first document on regional development, which defines country's development priorities. According to the new regional policy, role of state has been reduced to elimination and alleviation of the problems that certain regions are facing, i.e. increasing their capacity for autopropulsive development, especially in regions with specific development problems. In this Strategy, for the first time, three variants of economic regionalization of Serbia have been proposed, based on the definition of statistical regions according to the NUTS model (Nomenclature des unités territoriales statistiques) (GRS, 2007).

The adoption of the „Law on regional development” (Official Gazette of the RS, 51/2009, modified in 2010 and 2015) represents the highest progressive step regarding the territorial reorganization of Serbia. Although some concrete proposals for possible regionalization existed (Jovičić, 1996; Обрадовић, 2007; Оцокољић, 1997, 1998; Степић, 2002a, 2002b; Stojkov, 2007; Трипковић, 2003; Vacić et al., 2003, etc.), only after the adoption of this law, more serious work was initiated on the establishment of an institutional framework for the effective conduct of regional development policy and the 

and Reduction of Regional Inequalities

creation of an optimal regionalization of Serbia, which would, to the greatest extent, encourage more balanced regional development.

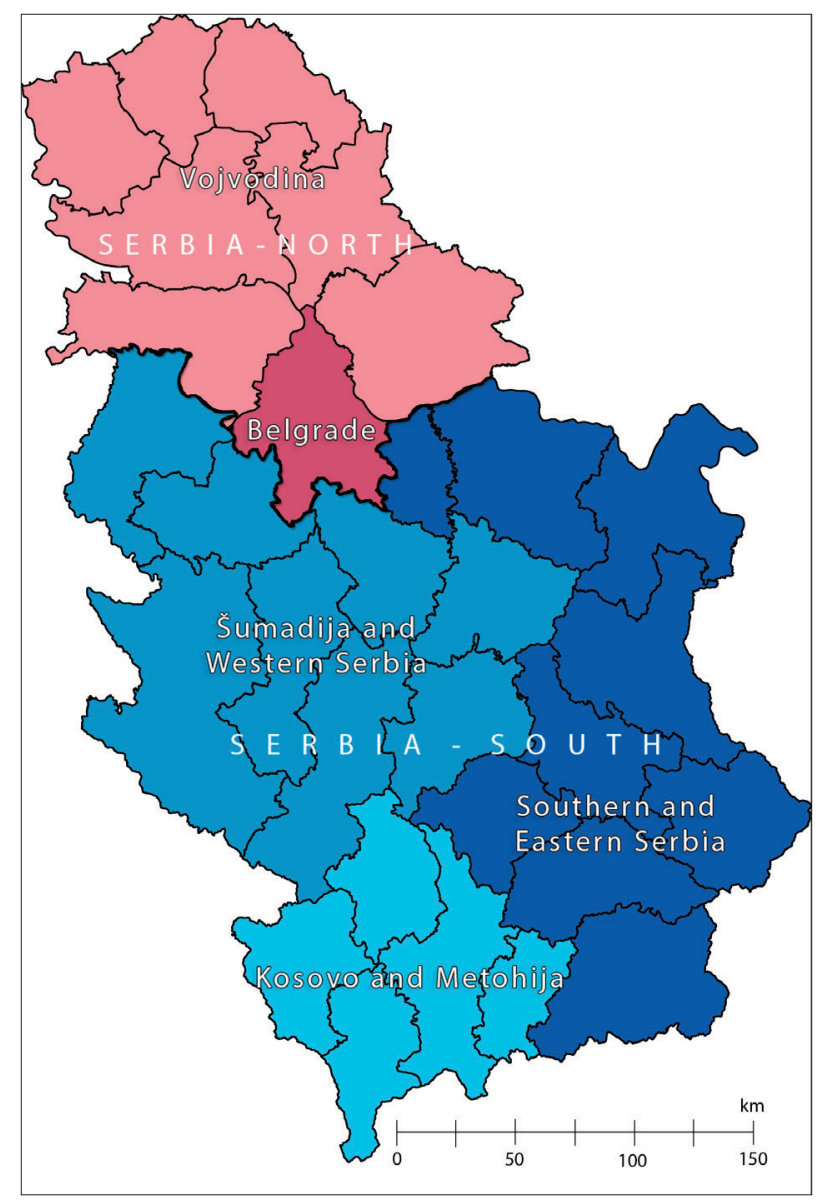

Maps 2 - NUTS regions of Serbia Source: Map processed by authors based on Regulation on nomenclature of statistical territorial units $(2009,2010)$.

Based on the "Law on regional development" (2009), the "Regulation on the nomenclature of statistical territorial units" was adopted (Official Gazette of the RS, 109/2009), which divided Serbia into two NUTS 1 regions, seven NUTS 2 regions and 30 NUTS 3 regions. The basis of this regionali- 
zation is NUTS 1 regions Serbia-North and Serbia-South (Map 2). Region Serbia-North was included two NUTS 2 regions - Vojvodina and Belgrade. The Region Serbia-South was divided into five NUTS 2 units: Western Region, Eastern Region, Central Region, Southern Region and Kosovo and Metohija (Ivanović, Gašić, Perić \& Krulj Mladenović, 2016; Vuković, Jovanović, Zakić \& Vukotić, 2011). Each NUTS 2 region is divided into areas (Serbian: oblasti) that coincide with the territories of the districts and belong to NUTS 3 level (Map 2). Each area is formed around one major urban center, or functional urban area. NUTS 3 regions consist of local self-government units (municipalities and cities). Criteria for the hierarchical division into three levels of NUTS region are based on the general criteria established by the standards of the European Union (population, geopolitical position, natural resources, existing territorial organization and cultural and historical heritage) (Radulović, Vuković, Voronov \& Simeunović, 2015).

The following year, by amendments to the „Law on regional development" (Official Gazette of the RS, 30/2010) and "Regulation on the nomenclature of statistical territorial units" (Official Gazette of the RS, 46/2010), number of NUTS 2 units in the Serbia-South region decreased from five to three: Šumadija and Western Serbia (created by the merging of the Western and Central regions), Southern and Eastern Serbia (created by the merging of the Southern and Eastern regions) and Kosovo and Metohija (Map 2). With these changes, Serbia has adopted statistical regions with smaller economic and demographic disparities in the function of more balanced regional development and more efficient use of EU pre-accession funds.

The legislative acts determined a large number of subjects of regional development of Serbia: the Government, relevant ministries, state institutions for regional development (councils, agencies and funds), local self-governments, etc. These bodies have been established in order to plan and implement a regional development policy. However, some of these institutions do not have clear roles and responsibilities. They have been strongly criticized for their development on personal commitment and connections (Guglielmetti \& Avlijaš, 2013; Parolari \& Trettel, 2015). Among the citizens of Serbia, it is right to ask whether a large number of subjects of regional development means only a new accumulation of bureaucratic apparatus and complication of procedures.

Key actors in the implementation of the new regional policy are development agencies and centers for development of small and medium-sized enterprises. The National Agency for Regional Development was established in 2009 in order to carry out regulatory tasks, determine the develop- 
ment priorities and assess the proposed development projects. After its abolition in 2016, this role was taken over by the Development Agency of Serbia, which has a network of 16 regional development agencies - in Belgrade, Požarevac, Zaječar, Niš, Leskovac, Novi Pazar, Loznica, Užice, Kraljevo, Kruševac, Kragujevac, Novi Sad, Subotica, Zrenjanin, Ruma and Kosovska Mitrovica (Development Agency of Serbia, 2017).

Table 1 - NUTS regions in Serbia

\begin{tabular}{|c|c|c|}
\hline NUTS 1 & NUTS 2 & NUTS 3 \\
\hline \multirow{8}{*}{ SERBIA-NORTH } & Belgrade & Belgrade \\
\hline & \multirow{7}{*}{ Vojvodina } & West Bačka \\
\hline & & South Banat \\
\hline & & South Bačka \\
\hline & & North Banat \\
\hline & & North Bačka \\
\hline & & Central Banat \\
\hline & & Srem \\
\hline \multirow{22}{*}{ SERBIA-SOUTH } & \multirow{8}{*}{ Šumadija and Western Serbia } & Zlatibor \\
\hline & & Kolubara \\
\hline & & Mačva \\
\hline & & Moravica \\
\hline & & Pomoravlje \\
\hline & & Rasina \\
\hline & & Raška \\
\hline & & Šumadija \\
\hline & \multirow{9}{*}{ Southern and Eastern Serbia } & Bor \\
\hline & & Braničevo \\
\hline & & Zaječar \\
\hline & & Jablanica \\
\hline & & Nišava \\
\hline & & Pirot \\
\hline & & Podunavlje \\
\hline & & Pčinja \\
\hline & & Toplica \\
\hline & \multirow{5}{*}{ Kosovo and Metohija } & Kosovo \\
\hline & & Kosovska Mitrovica \\
\hline & & Kosovsko Pomoravlje \\
\hline & & Peć \\
\hline & & Prizren \\
\hline
\end{tabular}

Source: Regulation on the nomenclature of statistical territorial units $(2009,2010)$. 


\section{Conclusion}

The NUTS regions in Serbia are the basis for the development of documents necessary for implementation of projects that should be financed from the European Union's structural funds. The nomenclature of statistical territorial units in Serbia should enable socio-economic analyzes of region and defining development programs for underdeveloped regions, and to provide a territorial, administrative and political framework for implementation of regional policy modeled on the European Union, i.e. to create an administrative and legal framework for development of underdeveloped regions using European Union's funds earmarked for this purpose. In addition, the basic level for the implementation of regional policy and the analysis of regional development problems is NUTS 2. The level of NUTS 3 (areas, i.e. districts of Serbia) includes territories that are too small for complex economic analysis, but should be used for specific analyzes or for deciding where concrete development measures should be taken.

However, the functioning of these regions in practice encounters many difficulties. Eight years after the adoption of the "Law on regional development", the NUTS regionalization of Serbia still largely exists only as a "dead letter". According to some authors, the „Law on regional development" and the established regions are more of a result of efforts to fulfill one of the obligations of Serbia in the process of European integration so that the state will formally be given the opportunity to access the development funds of the European Union, and not fulfill the constitutional obligation to systemic measures ensure a balanced development of all parts of the territory. National policy regarding regional development is inefficient, because it does not recognize or respect the existing statistical territorial units (NUTS region), which should be the basis for measuring of the level of development of certain parts of Serbia and the differences between them.

A significant problem also concerns the lack of jurisdiction of region, i.e. insufficient level of decision-making decentralization, so Serbia is still largely (de facto and de jure) centralized state. The hierarchy regions whose creation was initiated by the "Law on regional development" have no selfgoverning character, do not represent the levels of regional and local authorities and do not constitute elements of the territorial organization of the state. NUTS regions of Serbia are economic development units and statistical units, whose role consists in planning and implementation of regional development policy, and their creation is motivated by need to align with the nomenclature of statistical territorial units, which is applied in member states 
of the European Union. Since the NUTS regions in Serbia, as new territorial units, do not have autonomy in regional governance (the laws do not give these powers), they do not represent the middle level of government, and can not be able to decrease the differences in development on their own and support long-term economic and social development. It is therefore necessary that these territorial units get appropriate competencies in governance and decision-making, which would ensure de facto decentralization of the state and give a clear sense to the newly formed regions.

Relations between the Republic of Serbia and its regions, as well as relations between regions themselves, should be established in accordance with the principles of mutual respect, cooperation and solidarity. Regions should be given significantly higher powers, which means that they exercise administrative authority and sign contracts and agreements with other regions within Serbia. Regions would have ability to act at the international level (trans-national, trans-regional and trans-state cooperation), i.e. to conclude development agreements, contracts or protocols of cooperation that are international and approved by the Government of Serbia (in case the republican laws require it). In near future, it is necessary to create conditions for the equal development of all parts of Serbia and alleviating developmental inequalities, which can be achieved by a higher degree of decentralization, and not by the still presence dependence of Belgrade. From the point of view of the needs of the citizens of Serbia, the most important is that the adopted model of NUTS regionalization comes to life in practice, but also that the newly formed regions receive administrative functions and right to dispose of finances (instead the central government in Belgrade), because the lower levels of governance know best which projects need investing money, and the priorities of regional and local development - which is the main goal of new regionalization.

\section{Acknowledgements}

The paper is the result of the research within the project no. 176008 funded by the Ministry of Education and Science of the Republic of Serbia.

\section{References}

Adžić, S. (2015). Evolution of the regional policy and institutionalization of regionalization - a case study of Serbia. In: Drobyazko, S.I. (Ed.). Socio-economic aspects of economics and management (pp. 268-278). Taunton, MA: Aspect Publishing.

Constitution of the Republic of Serbia (1990). Official Gazette of the RS, 1/1990. 
Constitution of the Republic of Serbia (2006). Official Gazette of the RS, 98/2006.

Development Agency of Serbia (2017). Our services. Retrieved from http:/ / ras.gov.rs/en/about-us/our-services

Đurđev, A. (2007). Lokalna samouprava u Srbiji - od 1804. godine do tranzicije. Zbornik radova Pravnog fakulteta u Novom Sadu, 41(1/2), 7-20.

Đurić, V. (1959). Problematika geografske regionalizacije Srbije. Zbornik radova $V$ kongresa geografa FNR Jugoslavije. Cetinje: Geografsko društvo NR Crne Gore.

General Law on the areas of the counties and municipalities (1955). Official Gazette of Yugoslavia, 26/1955.

GRS (2007). Regional development strategy of Republic of Serbia 2007-2012. Belgrade: Government of Republic of Serbia.

Guglielmetti, C., \& Avlijaš, S. (2013). Regionalization and regional development in Serbia. In: Palermo, F. \& Parolari, S. (Eds.). Regional dynamics in Central and Eastern Europe (pp 201-239). Leiden: Martinus Nijhoff Publishers. doi: 10.1163/9789004242319_010

Ilešič, S. (1961). Geografska regionalizacija Jugoslavije. Geografski vestnik, 33, 3-23.

Ilić, V. M. (2015). Decentralization of EU member states and its effects on regional development: Experiences and recommendations for Serbia. Business Economics, 9(1), 77-94.

Ivanović, V., Gašić, M., Perić, G., \& Krulj Mladenović, M. (2016). Analysis of regional fevelopment of the Republic of Serbia in comparison with the European Union. Management and Education, 12(1), 1-6.

Jovičić, M. (1996). Regionalna država. Beograd: Izdavačka zajednica Vajat.

Kubović, B. (1961). Regionalni aspekt privrednog razvitka Jugoslavije. Zagreb: Društvo ekonomista Hrvatske.

Law on regional development $(2009,2010,2015)$. Official Gazette of the RS, 51/2009, 30/2010, 89/2015.

Law on territorial organization of the Republic of Serbia and local self-government (1991). Official Gazette of the RS, 47/1991.

Lončar, Z. (2009). Nastanak i razvoj ideje o regionalizaciji Srbije. Zbornik radova Pravnog fakulteta u Novom Sadu, 43(2), 333-344.

Malovrh, C. (1959). Prilog ekonomsko-geografskom rejoniranju Jugoslavije. Zbornik radova V kongresa geografa FNR Jugoslavije. Cetinje: Geografsko društvo NR Crne Gore. 
Marković, J.Đ. (1967). Geografske oblasti Socijalističke Federativne Republike Jugoslavije. Beograd: Zavod za izdavanje udžbenika SR Srbije

RZS (1986). Međuopštinske regionalne zajednice u SR Srbiji. Beograd: Republički zavod za statistiku SR Srbije.

Melik, A. (1949). Jugoslavija - zemljepisni pregled. Ljubljana: Državna založba Slovenije.

Milojević, B.Ž. (1955). O geografskim oblastima NR Srbije. Izveštaj o radu IV Kongresa geografa FNRJ, pp. 1-7. Beograd: Srpsko geografsko društvo.

Milosavljević, B. (2015). Dva veka lokalne samouprave u Srbiji. Beograd: Stalna konferencija gradova i opština - Savez gradova i opština Srbije

Obradović, S. (1955). Ekonomski rajoni Jugoslavije i problem rajoniranja. Ekonomski anali, 1.

Olfert, M.R. (2016). Regional inequality and decentralized governance: Canada's provinces. The Review of Regional Studies, 46(3), 201-222.

Parolari, S., \& Trettel, M. (2015). Regionalization in Central and Eastern Europe: limits and perspectives of an externally driven process. In: Palermo, F. \& Alber, E. (Eds.). Federalism as Decision-Making. Changes in Structures, Procedures and Policies (pp 358-377). Leiden: Brill Nijhoff. doi: 10.1163/9789004274518_020

Petrović, R. (1957). O problemu geografske rajonizacije Jugoslavije. Geografski pregled, 1, 104-135.

Prostorni plan Republike Srbije - Planska i analitičko-dokumentaciona osnova (1996). Beograd: Službeni glasnik sa p. o.

Radulović, D.M., Vuković, D.B., Voronov, M.P. \& Simeunović, I. (2015). Statistical territorial units with purpose of measuring level of development of regions in Serbia. Эко-потенцииал, 2, 87-99.

Regulation on the nomenclature of statistical territorial units $(2009,2010)$. Official Gazette of the RS, 109/2009, 46/2010.

Rogić, V. (1973). Regionalizacija Jugoslavije. Geografski glasnik, 35, 13-27.

Roglić, J. (1955). Prilog regionalnoj podjeli Jugoslavije. Geografski glasnik, $16 / 17,9-22$.

Stojkov, B. (2007). Status grada, decentralizacija i policentričnost Srbije. In: Milenković, D. \& Damjanović, D. (Eds.). U susret novom statusu gradova u Srbiji - realnost i potrebe (pp. 11-24). Beograd: PALGO centar. 
Takács, Z., \& Nagy, I. (2013). Institutionalization of regional policy and the regional institution system in Serbia. European Spatial Research and Policy, 20(1), 27-47. doi: 10.2478/ esrp-2013-0002

Tošić, D., \& Maksin-Mićić, M. (2007). The problems and potentials for the regionalization of Serbia. Ethnologia Balkanica, 11, 279-299.

Vacić, Z., Mijatović, B., Simić, A. \& Radović, Z. (2003). Regionalizacija Srbije. Beograd: Centar za liberalno-demokratske studije.

Vasović, M. (1965). Još jedan pokušaj geografske regionalizacije SR Srbije. Zbornik radova Geografskog zavoda PMF-a u Beogradu, 12, 111-128.

Vuković, D., Jovanović, A., Zakić, N., \& Vukotić, S. (2011). Nomenclature of statistical teritorial units: possibilities of application in Serbia. Journal of the Geographical Institute "Jovan Cvijić" SASA, 61(2), 11-24. doi:10.2298/IJGI1102011V

ZSNRS (1955). Administrationo-teritorijalne promene u NR Srbiji od 1834-1954. godine. Beograd: Zavod za statistiku NR Srbije.

Милетић, Р., Тодоровић, М. \& Миљановић, Д. (2009). Приступ неразвијеним подручјима у регионалном развоју Србије. Зборник радова Географског института „Јован Цвијић”, 59(2), 149-171.

Обрадовић, Д.Ђ. (2007). Модел регионализације централне Србије. Зборник радова Географоког института "Јован Цвијић”, 57, 309-317.

Оцокољић, М. (Ед.) (1997). Географрска структура и регионализачија Србије 1. Посебна издања, књ. 51. Београд: Географски институт „Јован Цвијић" САНУ.

Оцокољић, М. (Ед.) (1998). Географска структура и регионализаиија Србије 2. Посебна издања, књ. 53. Београд: Географски институт „Јован Цвијић" САНУ.

Степић, М. (2002а). Политичко-географрски аспекти регионализације Србије. Гласник Српског географског друштва, 82(1), 17-29.

Степић, М. (2002б). Регионализација у функцији унутрашње политичко-територијалне организације Србије. Зборник Матице српске за друштвене науке, 112/113, 127-147.

Тошић, Д. (2012). Принциии регионализације. Београд: Универзитет у Београду - Географски факултет.

Трипковић, М. (2003). Регионализација у Србији: између централизма и регионализма. Социолошки преглед, 37(1/2), 33-48. 